\title{
Preface
}

\section{The Story behind the Painting}

\section{I}

RETURNED TO NEW YORK IN 2009, TO PLAY CARNEGIE Hall. I had first moved there from my native North Carolina in 1977 , renting a room on Seventh Avenue, around the corner from the great concert hall, a perch from which I had watched as a small group of rabble-rousers at CBGB, a distant watering hole on the Bowery, transformed the rules of what was possible in handmade rock music. I had even waved a few flags in the revolution's march, first with a critically lauded rock band called the dB's and then as a solo recording artist and record producer. Now I was back for a benefit concert celebrating the music of R.E.M., a group of fellow Southerners and one of the most successful standard-bearers for that musical sea change.

Although I once knew every street corner and hotdog stand in Manhattan, I had left in I992, and the city had shape-shifted several times since then. I had returned this time with my wife, Dana, and my daughter, Julia, and before the concert we went 


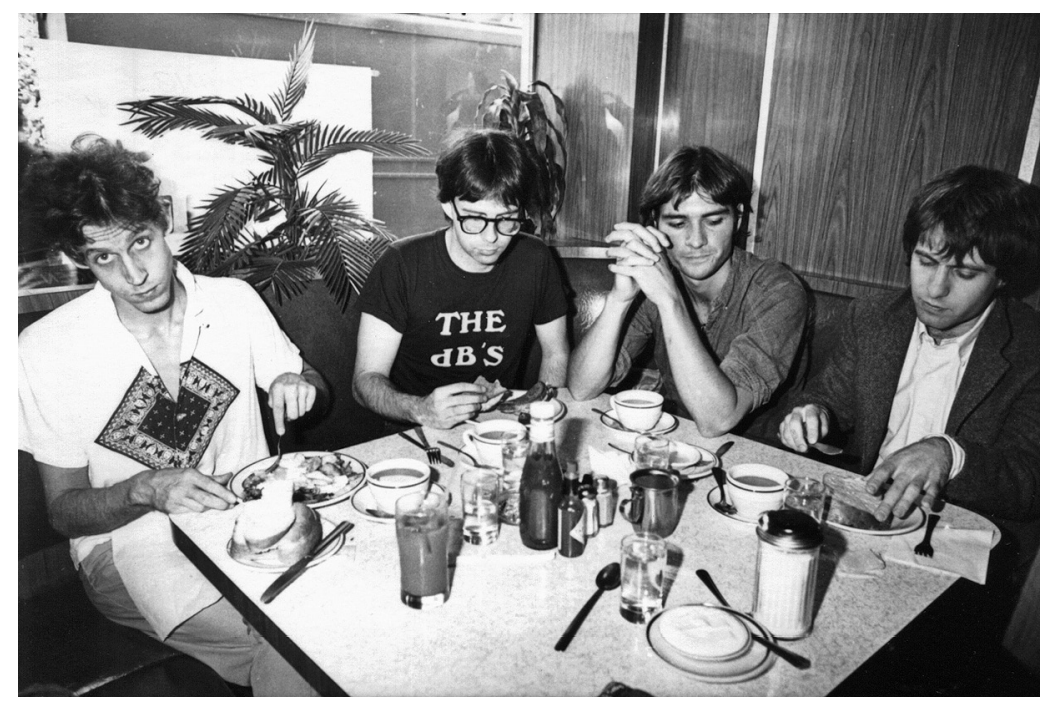

The dB's (left to right: Will Rigby, Peter Holsapple, Gene Holder, Chris Stamey) at Odessa Restaurant (New York City) in 1979; photo by Stephanie Chernikowski

walking in search of familiar signposts, accompanied by our friends Amanda and Lydia Kavanagh and Amanda's six-yearold daughter, Oona. We ended up at the bar of the Algonquin Hotel, the famed site of another insurrection led by influential malcontents: the Algonquin Round Table of Dorothy Parker, Harold Ross, Alexander Woollcott, et al.

You walk into the room there and immediately see its welllubricated history depicted in Natalie Ascencios's painting $A$ Vicious Circle, which hangs on the far wall next to the kitchen. We had already told ten-year-old Julia about the meaning of its mise-en-scène; she walked over to examine it closer. Oona followed close behind. Julia whispered to her, "There's a story behind this painting" and continued to study it. When she broke her gaze, she saw that little Oona was nowhere to be found. After a few frantic moments, the girl was discovered around the other side of the wall, in the kitchen, staring at the hung cutlery, to the amusement of the chef. 
When asked why she was there, Oona replied, "But you said there was a story behind the painting! . . I'm looking for it."

This is, first and foremost, my task here: to tell some of the stories behind my own hand-painted songs. Sometimes there will be a lot to say about a lyrical twist or melodic turn, a bit of backstory, specifics that perhaps add to or alter the enjoyment of the tunes. Sometimes I'll include crosstalk, bleed-through, from other music, other's stories, other rooms. Sometimes we'll end up in the kitchen, staring at the knives surrounded by layers of ghosts, past raconteurs, and fellow travelers.

There is another, familiar story here, however: a coming-ofage migration from a hinterland to a cultural capital. When I was twenty-two and freshly arrived in Manhattan, I suddenly found myself in a band with singer Alex Chilton, and in just a few weeks we were being reviewed favorably in The New York Times. One day at rehearsal, I mentioned being surprised that the best and most innovative players around us all seemed to be from out of town. Tom Verlaine and Richard Hell had arrived from Delaware to be poets together and then formed the band Television. The leader of Talking Heads, David Byrne, had entered the fray from Maryland by way of Rhode Island. Chilton, who was himself from Tennessee, told me what he believed: "Listen, good things come from the provinces." This is not strictly true, but coming to the big city and holding up a flame against its lights has long been a rite of passage for artists of all sorts. So many of my friends and I, from the Southern exposure of North Carolina, made this voyage together in the late seventies and early eighties, just as Carolina-bred musical giants Thelonious Monk, John Coltrane, Max Roach, and Nina Simone had done in years before. We brought parts of our provinciality with us, some Tar Heel-adhesive determination and innocence, and in return absorbed equal parts of New York's frontier abandon. Whether we stayed for only a short time or never left, we pilgrims in those heady, uncharted days were forever changed by this.

During my days in Manhattan, there were no cell phones with earbuds to blot out the city sounds (the Sony Walkman arrived 
in 1979 but wasn't ubiquitous for another decade). We all shared the air. And music leaked in everywhere, from huge, swinging portable cassette blasters, club doorways, bodega radios-the whole city was a mix tape. It was a town of loud, then. Every thoroughfare could be an "Electric Avenue," as Eddy Grant's I983 smash proclaimed. And the DJs in the clubs were curators more than creators, proud of getting the latest platter from London or Athens, Georgia, eager to turn you on to something new. To replicate this flavor of the era, and since all my songwriting in those years occurred in the context of this sonic smorgasbord, I've included some Jukebox sections, my chance to play DJ for you.

It's funny how things turn out. I never meant this book to be any kind of memoir. It began solely as an annotated songbook, concise paragraphs attached to sheet music, words and melodies and chords suitable for parlor playing in the old way. But from the git-go, I pretty much failed at the "concise" part. The annotations grew and grew until, in the end, they took on a life of their own. Each chapter here is named after a line from the song that was originally its inspiration. 